\title{
Clinical Outcome after Percutaneous Coronary Intervention in Patients with Prior Renal Transplantation
}

\author{
Fábio Trentin ${ }^{1}$, Eduardo França Pessoa de Melo², Carlos Vinicius Abreu do Espírito Santo ${ }^{3}$, \\ Flavio Jota de Paula ${ }^{4}$, William Carlos Nahas ${ }^{5}$, André Gasparin Spadaro ${ }^{6}$, Jose Jayme de Lima ${ }^{7}$, \\ Luiz Henrique Gowdak ${ }^{8}$, Carlos Augusto Homem de Magalhães Campos ${ }^{9}$, Pedro Alves Lemos Neto ${ }^{10}$
}

\begin{abstract}
Background: Coronary artery disease is a major cause of death in patients with chronic kidney disease. Moreover, due to the high prevalence of risk factors for atherosclerosis, many of these patients require percutaneous coronary intervention $(\mathrm{PCl})$ even after renal transplantation. The aim of this study is to report the late follow-up of patients with renal transplantation treated with $\mathrm{PCl}$ and stenting. Methods: Patients $>18$ years of age, with prior kidney transplantation, and treated with $\mathrm{PCl}$ were included. Clinical follow-up was evaluated by medical record analysis and telephone contact. The study endpoint was the incidence of major adverse cardiac events (MACE) during follow-up. Results: Twenty-nine patients were included. Mean age was $54.8 \pm 8$ years and the majority male $(72.4 \%)$. The prevalence of hypertension was $89.7 \%$, dyslipidemia $69 \%$ and diabetes $51.7 \%$. Most of them had multivessel disease (2-vessel: 44.8\%; 3-vessel: $41.4 \%$ ). Lesion complexity was high, being $84.3 \%$ type B2 or $\mathrm{C}$ lesions and $27.5 \%$ bifurcation lesions. Procedural success rate was $100 \%$. Bare metal stents were used in $96.6 \%$ of cases. The follow-up time was 1,378 \pm 977 days. The mortality rate was $25.1 \%$, target vessel revascularization rate was $15.9 \%$ and none of the patients presented nonfatal infarction. The incidence of MACE during follow-up was $34.5 \%$. Conclusions: Late follow-up after $\mathrm{PCI}$ in renal transplantation patients demonstrated a high probability of
\end{abstract}

RESUMO

\author{
Evolução Clínica após Intervenção \\ Coronária Percutânea em Indivíduos \\ com Transplante Renal Prévio
}

Introdução: A doença arterial coronária é uma das principaiscausas de óbito em pacientes com doença renal crônica. Alémdisso, em decorrência da elevada prevalência de fatores de risco para aterosclerose, muitos desses pacientes necessitam de intervenção coronária percutânea (ICP) mesmo após o transplante renal. O objetivo deste estudo é descrever a evolução tardia de pacientes transplantados renais submetidos à ICP com stent. Métodos: Foram incluídos pacientes transplantados renais, com idade $>18$ anos, tratados com ICP. O seguimento foi realizado por análise de prontuários e contato telefônico. O desfecho do estudo foi a incidência de eventos cardíacos adversos maiores (ECAM) durante o seguimento. Resultados: Foram incluídos 29 pacientes. A média de idade foi de 54,8 \pm 8 anos, sendo a maioria do sexo masculino $(72,4 \%)$. A prevalênciade hipertensão arterial sistêmica foi de $89,7 \%$, de dislipidemia de $69 \%$; e de diabetes, de 51,7\%. A maior parte apresentava doença multiarterial (biarterial, 44,8\%; triarterial, $41,4 \%$ ). A complexidade das lesões foi elevada, sendo $84,3 \%$ dos tipos B2 ou C e 27,5\% com lesões em bifurcação. A taxa de sucesso do procedimento foi de $100 \%$. Stents convencionais foram utilizados em $96,6 \%$ dos casos. O tempo de seguimento foi de $1.378 \pm 977$ dias. A mortalidade foi de $25,1 \%$, a taxa

\footnotetext{
${ }^{1}$ Resident physician at the Hemodynamics and Interventional Cardiology Service of Instituto do Coração do Hospital das Clínicas da Faculdade de Medicina da Universidade de São Paulo. São Paulo, SP, Brazil.

${ }^{2}$ Resident physician at the Hemodynamics and Interventional Cardiology Service of Instituto do Coração do Hospital das Clínicas da Faculdade de Medicina da Universidade de São Paulo. São Paulo, SP, Brazil. ${ }^{3}$ Resident physician at the Hemodynamics and Interventional Cardiology Service of Instituto do Coração do Hospital das Clínicas da Faculdade de Medicina da Universidade de São Paulo. São Paulo, SP, Brazil. ${ }^{4}$ Doctor. Physician at the Renal Transplantation Unit of Hospital das Clínicas da Faculdade de Medicina da Universidade de São Paulo. São Paulo, SP, Brazil.

${ }^{5}$ Titular professor of the Urology Subject - Renal Transplantation Service of Hospital das Clínicas da Faculdade de Medicina da Universidade de São Paulo. São Paulo, SP, Brazil.

6 Interventionist cardiologist physician at the Hemodynamics and Interventional Cardiology Service of Instituto do Coração do Hospital das Clínicas da Faculdade de Medicina da Universidade de São Paulo. São Paulo, SP, Brazil.
}

\begin{abstract}
${ }^{7}$ Full professor. Cardiologist physician at the Hypertension Unit of Instituto do Coração do Hospital das Clínicas da Faculdade de Medicina da Universidade de São Paulo. São Paulo, SP, Brazil.

${ }^{8}$ Full professor. Cardiologist physician at the Clinical Unit of Chronic Coronary Disease of Instituto do Coração do Hospital das Clínicas da Faculdade de Medicina da Universidade de São Paulo. São Paulo, SP, Brazil ${ }^{9}$ Interventionist cardiologist physician at the Hemodynamics and Interventional Cardiology Service of Coração do Hospital das Clínicas da Faculdade de Medicina da Universidade de São Paulo. São Paulo, SP, Brazil.

${ }^{10}$ Full professor. Director of the Hemodynamics and Interventional Cardiology Service of Instituto do Coração do Hospital das Clínicas da Faculdade de Medicina da Universidade de São Paulo. São Paulo, SP, Brazil.
\end{abstract}

Correspondence to: Pedro Alves Lemos Neto. Av. Dr. Enéas Carvalho de Aguiar, 44 - São Paulo, SP, Brazil - CEP 05403-000

E-mail: pedro.lemos@incor.usp.br

Received on: 03/04/2013 • Accepted on: 05/14/2013 
clinical events. However, the study population was a sample of high clinical and angiographic complexity.

DESCRIPTORS: Angioplasty. Stents. Coronary disease. Kidney transplantation.

$\mathrm{T}$ he increasing prevalence of chronic kidney disease and consequent increased demand for renal replacement therapy has induced increased rates of renal transplantation worldwide. ${ }^{1}$ Only in Brazil, in the first half of 2012, 2,689 kidney transplantations were performed. ${ }^{2}$ In this context, there is an increased concern regarding this specific part of the population, aiming to identify their clinical peculiarities and to understand the comorbidities that develop over time. ${ }^{3}$

In recent years, chronic kidney disease has been confirmed as a condition very frequently associated with coronary artery disease, which is one of leading causes of death in patients who require substitutive therapy. ${ }^{4}$ In a recent study of patients who underwent renal transplantation, after a period of 2.9 years, $32.8 \%$ had altered non invasive tests for assessment of myocardial ischaemia and $14.5 \%$ had angiographically significant lesions in the coronary angiography. ${ }^{5}$

In this scenario, percutaneous coronary intervention $(\mathrm{PCl})$ has been increasingly used in renal transplantation patients, especially because it is a less invasive procedure when compared with the surgical alternative, following its specific indications. Moreover, in general, mortality between percutaneous and surgical revascularization alternatives is very similar in this population. ${ }^{6}$

Few studies have analyzed the long-term evolution of patients with prior renal transplantation treated with $\mathrm{PCl}$ and stenting. Research on this subject is of considerable interest, since it not only allows for the evaluation of the influence of classical risk factors for the development of coronary artery disease, but also for speculation on the impact of the characteristics of renal transplantation recipients, including the use of already tested immunosuppressive drugs to reduce intrastent restenosis. ${ }^{7-9}$

This study aimed to describe the late evolution in patients with a history of renal transplantation submitted to $\mathrm{PCl}$ with stenting.

\section{METHODS}

This was a retrospective, single-center study, conducted at a tertiary care, high-complexity cardiology de revascularização do vaso-alvo foi de $15,9 \%$ e nenhum paciente apresentou infarto não fatal. A incidênciade ECAM durante a evolução foi de $34,5 \%$. Conclusões: A evolução clínica tardia após ICP em pacientes transplantados renais demonstrou elevada probabilidade de eventos clínicos. No entanto, a população estudada foi uma amostra de altacomplexidade clínica e angiográfica.

DESCRITORES: Angioplastia. Stents. Doença das coronárias. Transplante de rim.

service. The research was based on the analysis of the database, medical records review, and telephone contact.

\section{Study population}

Between March 2002 and June 2011, 36 patients with prior renal transplantation were treated with $\mathrm{PCl}$ at the Instituto do Coração do Hospital das Clínicas, School of Medicine, Universidade of São Paulo (Incor/ HCFMUSP, São Paulo, SP, Brazil). Seven patients were excluded, as they did not have any new consultations recorded in their medical charts and it was not possible to complete the follow-up by telephone. A total of 29 subjects comprised the final population of the analysis.

\section{Procedure}

Unfractionated heparin at a dose from $70 \mathrm{U} / \mathrm{kg}$ to $100 \mathrm{U} / \mathrm{kg}$ was previously administered in all the procedures, aimed at obtaining activated clotting time between 250-300 seconds; the patients were receiving dual antiplatelet therapy with acetylsalicylic acid 100 $\mathrm{mg}$ and clopidogrel $75 \mathrm{mg}$.

The choice of access route, techniques, and materials, as well as diagnostic and intervention methods was made at the surgeon's discretion. All cases received at least one bare-metal stent (BMS) or drug-eluting stent (DES) with diameters varying between $2.5 \mathrm{~mm}$ and 4 $\mathrm{mm}$. Angiographic success was considered with residual stenosis $<30 \%$ after $\mathrm{PCl}$.

\section{Data collection}

Clinical and angiographic characteristics were obtained from the database of the Service of Hemodynamics and Interventional Cardiology of InCor/HCFMUSP. Information on the use of immunosuppressants was also assessed in each case.

The investigation of the events was performed using information obtained through medical record review and telephone contact. For cases in which the same event occurred more than once for the same patient, the repeated event was disregarded in the temporal analysis.

The study outcome was the occurrence of major adverse cardiac events (MACE) during follow-up, defined 
as death from any cause, acute myocardial infarction, and target vessel reintervention.

\section{Statistical analysis}

Analysis of the clinical and angiographic data was performed using the SPSS software (IBM Corp. - New York, United States). Continuous variables were described as mean and standard deviation, while categorical variables were described as frequencies and percentages. The event rate was estimated by Kaplan-Meier method.

\section{RESULTS}

The mean age was $54.8 \pm 8$ years and most of the subjects were males $(72.4 \%)$. The prevalence of hypertension was $89.7 \%$; dyslipidemia, 69\%; diabetes, $51.7 \%$; and previous or current history of smoking, $48.3 \%$. The clinical picture that motivated the $\mathrm{PCl}$ was, in most cases, acute coronary syndrome without ST-segment elevation, observed in $55.2 \%$ of cases, followed by acute coronary syndrome with ST-segment elevation in $27.6 \%$. All others were diagnosed with stable angina (Table 1).

On average, patients had $6 \pm 6$ years since the transplantation. The prescription of immunosuppressants was available for 23 patients, and the drugs most often prescribed were mycophenolate $(56.5 \%)$, prednisone (47.8\%), and tacrolimus (39.1\%) (Table 1).

Most cases had a multivessel obstructive pattern (two-vessel, 44.8\%; three-vessel, 41.4\%). Lesion complexity was high; $79.3 \%$ were type $\mathrm{B} 2$ or C lesions, and $27.5 \%$ involved bifurcations lesions, $24.1 \%$ lesions with thrombus, and $17.2 \%$ ostial lesions. De novo lesions were treated in all cases. BMS were used in 96.6\% of the cases, and angiographic success was attained in $100 \%$ of cases (Table 2).

The meantime of follow-up after $\mathrm{PCl}$ was 1,378 \pm 977 days. During this period, $34.5 \%$ of patients had at least one MACE. The incidence of adverse events occurred throughout the study period (Fig. 1). Mortality during follow-up was $25.1 \%$. None of the patients had nonfatal acute myocardial infarction in the period, and $15.9 \%$ required target vessel reintervention.

\section{DISCUSSION}

According to previous studies, the incidence of coronary atherosclerosis substantially higher in renal transplantation patients than in the general population. ${ }^{10}$ Moreover, the risk for development of coronary artery disease is high, even before the progression to end-stage renal disease. ${ }^{11}$

This study evaluated the long-term evolution of patients treated with $\mathrm{PCl}$ and stenting in this specific population of transplanted patients. The authors consider the research relevant, as it allows for a better evaluation
TABLE 1

Clinical characteristics

\begin{tabular}{|c|c|}
\hline Variable & $\mathrm{n}=\mathbf{2 9}$ \\
\hline Age, years & $54.8 \pm 8$ \\
\hline Male gender, n (\%) & $21(72.4)$ \\
\hline Diabetes & $15(51.7)$ \\
\hline Systemic arterial hypertension, n (\%) & $26(89.7)$ \\
\hline Dyslipidaemia, n (\%) & $20(69)$ \\
\hline Smoking, n (\%) & $14(48.3)$ \\
\hline $\begin{array}{l}\text { Family history of early coronary artery } \\
\text { disease, } \mathrm{n}(\%)\end{array}$ & $2(6.9)$ \\
\hline Previous stroke, n (\%) & $1(3.4)$ \\
\hline Peripheral vascular failure, n (\%) & $2(6.9)$ \\
\hline Previous acute myocardial infarction, n (\%) & $3(10.3)$ \\
\hline $\begin{array}{l}\text { Previous percutaneous coronary } \\
\text { intervention, } \mathrm{n}(\%)\end{array}$ & $3(10.3)$ \\
\hline $\begin{array}{l}\text { Previous coronary artery bypass graft } \\
\text { surgery, } \mathrm{n}(\%)\end{array}$ & $4(13.8)$ \\
\hline \multicolumn{2}{|l|}{ Clinical picture, n (\%) } \\
\hline Stable angina & $5(17.2)$ \\
\hline $\begin{array}{l}\text { Acute coronary syndrome without } \\
\text { ST-segment elevation }\end{array}$ & $16(55.2)$ \\
\hline $\begin{array}{l}\text { Acute coronary syndrome with } \\
\text { ST-segment elevation }\end{array}$ & $8(27.6)$ \\
\hline Immunosuppressants & $\mathrm{n}=23$ \\
\hline Tacrolimus & $9(39.1)$ \\
\hline Cyclosporine & $4(17.4)$ \\
\hline Mycophenolate & $13(56.5)$ \\
\hline Sirolimus & $1(4.3)$ \\
\hline Azathioprine & 0 \\
\hline Prednisone & $11(47.8)$ \\
\hline
\end{tabular}

of the results of percutaneous treatment in patients with such particular characteristics, through the analysis of a significant sample of patients with these characteristics.

The occurrence of MACE in approximately onethird of patients over a period of more than three years indicates that, even with partial renal function or fully recovered, the sample reflects a population at high risk for developing severe events. ${ }^{12}$

Considering that only one study patient was treated with DES, where as all the others were treated with BMS $(96.6 \%)$, the need for target vessel reintervention in $15.9 \%$ of cases was an interesting result. In the general population, intrastent restenosis (which results from excessive neointimal proliferation after BMS implantation)occurs in $20 \%$ to $30 \%$ of cases, determining higher rates of target vessel reintervention than those 
observed in the present study. ${ }^{13-15}$ This result may be associated with a potential benefit of the immunosuppressive therapy, reaffirming what has been suggested in previous studies $7-9,16$

During the follow-up period, in one-quarter of the patients, mortality from all causes was the major component of the high occurrence of MACE. This high

TABLE 2

Angiographic characteristics

\begin{tabular}{lc}
\hline Variable & $\mathbf{n}=\mathbf{2 9}$ \\
\hline Arterial pattern, n (\%) & \\
One-vessel & $4(13.8)$ \\
Two-vessel & $13(44.8)$ \\
Three-vessel & $12(41.4)$ \\
Total lesions & $1.64 \pm 0.7$ \\
Ostial lesion, n (\%) & $5(17.2)$ \\
Bifurcation, n (\%) & $8(27.5)$ \\
Ulcerated plaque, n (\%) & $8(27.5)$ \\
Thrombus, n (\%) & $7(24.1)$ \\
De novo lesion, n (\%) & $29(100)$ \\
Type of lesion, n (\%) & \\
A & $2(6.9)$ \\
B1 & $4(13.8)$ \\
B2 & $16(55.1)$ \\
C & $7(24.2)$ \\
Drug-eluting stent, n (\%) & $1(3.4)$ \\
Sucesso angiográfico por Angiographic & $29(100)$ \\
success, n (\%) & \\
\hline
\end{tabular}

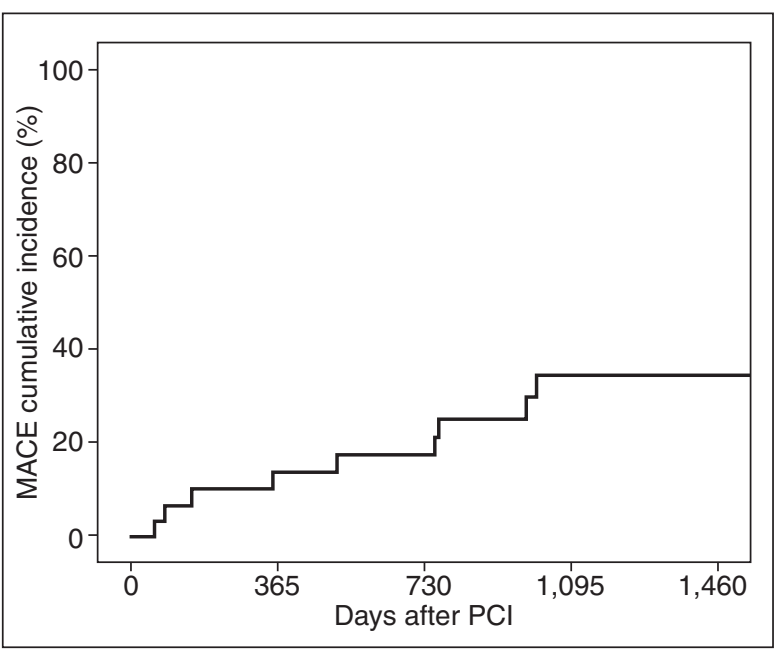

Figure - Incidence of major adverse cardiac events (death, acute myocardial infarction or target vessel reintervention) during follow-up. MACE, major adverse cardiac events; ICP, percutaneous coronary intervention. death rate is expected in this population group, since, in addition to the high underlying cardiovascular risk, the impaired immune capacity (caused by the chronic kidney disease itself and the use of immunosuppressants) is associated with a higher risk of developing severe comorbidities, such as infections and malignancies, which are potentially life-threatening. ${ }^{3,17}$

\section{Study limitations}

The study has some limitations, including the fact that it was retrospective, based on information obtained from a database and medical records, as well as telephone contact, which was not possible in all cases. There was, therefore, loss of a non-negligible portion of patients who could not be included the final analysis. Moreover, the inclusion of patients who had their procedures performed at very different times, especially in an area of cardiology in which there are constant advances in the methods, materials, and medications, caused some individuals to receive slightly differentiated treatment.

\section{CONCLUSIONS}

In the present study, late clinical outcome after $\mathrm{PCl}$ in renal transplantation patients showed a high likelihood of clinical events. However, the population studied was a sample of high clinical and angiographic complexity. The rate of target vessel revascularization was reduced, but this finding needs to be better evaluated in studies with larger sample sizes.

\section{CONFLICTS OF INTEREST}

The authors declare no conflicts of interest.

\section{REFERENCES}

1. Sociedade Brasileira de Nefrologia. Censo de Diálise [Internet]. São Paulo; 2011 [citado 2013 mar. 28]. Disponível em: http:// www.sbn.org.br/pdf/censo_2011_publico.pdf

2. Brasil. Ministério da Saúde. Sistema Nacional de Transplantes [Internet]. Brasília; 2012 [citado 2013 mar. 28]. Disponível em: http://portalsaude.saude.gov.br/portalsaude/arquivos/pdf/2012/ Set/27/transplantes_270912_final.pdf

3. Oliveira MIG, Santos AM, Salgado Filho N. Análise da sobrevida e fatores associados à mortalidade em receptores de transplante renal em Hospital Universitário no Maranhão. J Bras Nefrol. 2012;34(3):216-25.

4. Peres LAB, Biela R, Herrmann M, Matsuo T, Ann HK, Camargo MTA, et al. Estudo epidemiológico da doença renal crônica terminal no oeste do Paraná: uma experiência de 878 casos atendidos em 25 anos. J Bras Nefrol. 2010;32(1):51-6.

5. Kahn MR, Fallahi A, Kim MC, Esquitin R, Robbins MJ. Coronary artery disease in a large renal transplant population: implications for management. Am J Transplant. 2011;11(12):2665-74.

6. Herzog CA, Ma JZ, Collins AJ. Long-term outcome of renal transplant recipients in the United States after coronary revascularization procedures. Circulation. 2004;109(23):2866-71.

7. Versaci F, Gaspardone A, Tomai F, Ribichini F, Russo P, Proietti I, et al. Immunosuppressive Therapy for the Prevention of Restenosis After Coronary Artery Stent Implantation (IMPRESS Study). J Am Coll Cardiol. 2002;40(11):1935-42. 
8. Mota FM, Araújo J, Arruda JA, S Júnior HT, Pestana JOM, Sousa JMA, et al. Evolução clínica pós-stent coronariano em pacientes submetidos a transplante de rim. Arq Bras Cardiol.2007;88(5):521-4

9. Brito FS Jr, Rosa WC, Arruda JA, Tedesco H, Pestana JO, Lima VC. Efficacy and safety of oral sirolimus to inhibit in-stent intimal hyperplasia. Catheter Cardiovasc Interv. 2005;64(4):413-8.

10. Kasiske BL, Guijarro C, Massy ZA, Wiederkehr MR, Ma JZ. Cardiovascular disease after renal transplantation. J Am Soc Nephrol. 1996;7(1):158-65.

11. Joki N, Hase H, Nakamura R, Yamaguchi T. Onset of coronary artery disease prior to initiation of hemodialysis in patients with end-stage renal disease. Nephrol Dial Transplant.1997;12(4):718-23.

12. Sarnak MJ, Levey AS, Schoolwerth AC, Coresh J, Culleton B, Hamm L, et al. Kidney disease as a risk factor for development of cardiovascular disease. Circulation. 2003;108(17): 2154-69.
13. Kastrati A, Schömig A, Elezi S, Schühlen H, Dirschinger J, Hadamitzky $M$, et al. Predictive factors of restenosis after coronary stent placement. J Am Coll Cardiol. 1997;30(6): 1428-36.

14. Mercado N, Boersma E, Wijns W, Gersh BJ, Morillo CA, de Valk V, et al. Clinical and quantitative coronary angiographic predictors of coronary restenosis: a comparative analysis from the balloonto-stent era. J Am Coll Cardiol. 2001;38(3):645-52

15. Mehran R, Dangas G, Abizaid AS, Mintz GS, Lansky AJ, Satler $L F$, et al. Angiographic patterns of in-stent restenosis classification and implications for long-term outcome. Circulation. 1999;100(18):1872-8.

16. Arruda JA, Costa MA, Brito FS Jr, Tedesco H, Barbosa $A H$, Ribeiro EP, et al. Effect of systemic immunosuppression on coronary in-stent intimal hyperplasia in renal transplant patients. Am J Cardiol. 2003;91(11):1363-5.

17. Braun WE. Long-term complications of renal transplantation. Kidney Int. 1990;37(5):1363-78. 